\title{
ONLINE AND DISTANCE LEARNING IN SUDANESE UNIVERSITIES: A NECESSITY IN THE LIGHT OF THE COVID-19 PANDEMIC
}

\author{
Prof.G.K.Viju \\ Professor \& Dean (E-Learning), \\ University of Garden City, Khartoum, Sudan
}

\begin{abstract}
Considering the growing concerns about the outbreak of Covid-19, a large number of educational institutions around the world have been shut down in connection with face-to-face classes. Because of this virus, damage to education has increased; As we face the unpredictable future found around the world, we need to provide our society as a whole with flexible and vibrant education systems. In this paper, a meta-analysis method is adopted and the related literature. Relevant literature was conducted to entrap the core of further study during the period. Findings show that universities around the world are increasingly moving toward online education or elearning. The study also shows that ICT is an important component of integrated learning, in addition to a variety of resources such as staff willingness, trust, student reachability, and stimulus. This paper suggests that faculty members should use and use technology and technical clothing to enhance learning during these unexpected times. This suggests that online and distance learning is a requirement during lock-down and social distance due to the Covid-19 pandemic.
\end{abstract}

Keywords - ICT, Technology, Digital Transformation, Learning Platform, Covid-19, Online Teaching

\section{INTRODUCTION}

Governments and academic institutions around the world are presenting various policy initiatives to continue teaching activities in the wake of the Covid-19 explosion. Still, there is ambiguity and disagreement about what to show, how to teach, how much teachers and students work, what the classroom environment is like, and what impact this has on education equality. During the Covid-19 pandemic, in Extensive national efforts to use technology to support distance learning are emerging from distance learning and online learning. Researchers point out some of the shortcomings of online teaching are emerging. Researchers point out some of the shortcomings of online teaching infrastructure, such as teacher experience, knowledge gap, complex environmental acceptance, teacher resistance, and job security. However, with these limitations, the current situation will not affect the education of scholars in any way. For example, during the Covid-19 Pandemic Lockdown, the Sudanese class no-end learning policy was introduced to ensure that learning was never compromised. This is one of several policies proposed by Sudan to determine whether national lockdowns and college closures have not affected student learning. To address such issues, both current and future, I would like to suggest that governments and educators should further promote the development of academic information, considering furnishing teachers and students with standard teaching-learning tools at home. Train and support academic research on distance learning, particularly helping student's education with learning disabilities online.

The crisis is exacerbating pre-existing educational inequality by reducing the opportunities for the most vulnerable children, youth, and adults - the poor or those living in rural areas, girls, refugees, the disabled and the forced deportees.. The loss of education threatens to extend beyond this generation and erode decades of progress, and does not support access to education and the bonding of girls and young women. There will not be another 23.8 million children and young people (from preschool to tertiary education) Due to the financial impact of the epidemic, the school disruption can and will have a significant impact on education over the next year the provision of basic services to children and communities The employability of many parents, including the provision of nutritious food, increases the risk of violence against women and girls.

As financial pressures increase and development assistance becomes more difficult, funding for education will also face major challenges, which will widen the pre-Covid-19 education funding gaps. For example, for low-income and low-middle-income countries, that gap has reached \$ 148 billion a year, and could now increase to a third. Instead, this crisis has fueled reform in the schooling sector. We see innovative approaches that support the continuity of education and training: from radio and television to take-away packages. Distance learning solutions have been developed subsequently the rapid response from governments and partners around the world to support the continuation of education, including the Global Education Alliance, a UNESCO agreement. We were 


\section{International Journal of Engineering Applied Sciences and Technology, 2021 \\ Vol. 5, Issue 10, ISSN No. 2455-2143, Pages 11-19 \\ Published Online February 2021 in IJEAST (http://www.ijeast.com)}

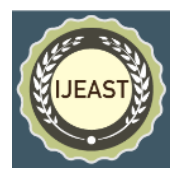

mentioned of the essential role of teachers play and the fact that governments and other key contributors have an obligation to take care for education officials. However, these changes underscore the bright future of learning and the accelerated changes in the methods of delivering quality education that indivisible from the need to hold someone back. This applies to children and young people who lack resources or who give the environment to access to learning. This is especially true of the teaching profession and for its excellent training and support in new methodology for the educational delivery, not least, of all for the educational community, including local communities, which rely on continuity of education in times of emergency and are key in building the best education.

The COVID-19 dilemma and unprecedented educational barrier are not over. 100 countries around the world have not yet announced a date for the opening of schools, and governments, unions, parents and children are learning instantly when to approach the next step. Based on the grade level, countries began planning to reopen schools nationwide, giving priority to exam classes or through localized openings in virus-free areas. However, given the persistent virus outbreak, a survey conducted in May-June 2020 found that most countries have not set a reopening date. These decisions have far-reaching social and economic repercussions and have lasting consequences for teachers, children, youth, and their parents - especially women, and societies as a whole.

Subsequently, the Sudanese government banned face-to-face activities, including teaching, in order to contain COVID-19. Sudan's Ministry of Higher Education (MoHE) has introduced an initiative to provide hundreds of millions of students with effective online learning from their homes using Moody with the help of the Open University platform. The rapid advancement of information and communication technology (ICT) and the increasing complexity with its explosive potential explains why the unification of technology in education is receiving special attention, especially in the situation of the COVID-19 pandemic witnessed the early entry of the Internet Generation into our institutions of higher learning, for which the staff is demanding a new generation of students with special interests and attitudes. This is due to the fact that their introduction into the world came at a time when technological development was ubiquitous and widespread around the world. A previous study by the author showed that the students have a strong connection to ICT and because of these clear findings and the massive blockade in The Current COVID-19 Pandemic, provided the internal impetus for this study.

\section{THE IMPORTANCE OF LEARNING}

The findings of this study are considered of great importance to the different participants for a number of reasons. More importantly, there is a lack of prior research on how higher- level institutions are trying to cope with student interaction during the COVID-19 pandemic. and the closure of many high-level institutions globally. This study will help identify critical areas and contribute to local literature on the subject, which can be used by relevant authorities to improve their educational initiatives. The importance of studying in technology Information and online modes can be understood as a way to improve your teaching skills. The findings of this study allow higher education institutions to strengthen their programs to better prepare teachers by providing vital knowledge on integrated teaching of ICTs and enable them to meet the diverse needs of the Covid -19 Pandemic. The study makes a significant contribution to their findings by revealing the differences between various groups and their attitudes towards the integration of ICT in teaching and learning. By constantly interacting with students, their findings will be highly valued by staff, who will be able to better understand their behavior and amicably solve management problems online. In a similar vein, ICT will allow educational authorities to incorporate important information about benefits of integrated learning in pedagogical reforms in education. In particular, they may need to revise their curriculum, thereby incorporating ICT knowledge into their curriculum at the primary and secondary levels.

This transformation will equip students with ICT integrated pedagogy in Higher Educational institutions. Then, if the study's recommendations are implemented, higher education institutes will be able to create an interactive and enjoyable learning environment for all students while they are locked out across the country due to the COVID-19 pandemic. Learning environments are a variety of platforms like Zoom, Jitsi, Google Meet, etc., where users engage and engage to learn new skills. Although students can learn in a number of settings, the term implies a more preferred and accurate alternative to the traditional classroom. (Stadler-Allman, 2015).

\section{METHODOLOGY}

An exploratory research design was found to be the most appropriate to uncover the main complexities associated with online learning in the context of COVID-19 due to global lockdown and social distancing. Scouting studies are a beneficial way of asking questions to establish basic information that can later be used as a launching pad for future research. Although qualitative research has long been of interest in the field of psychiatry, a meta-analysis of the qualitative literature is also known as meta-synthesis. A qualitative meta-analysis, also known as a synthesis metaanalysis, allows qualitative studies for the systematic review. Encourages meta-analysts to consider the methodological integrity of their research in relation to core research processes, including identifying a set of preliminary research studies and transforming preliminary findings into categories or themes in an organized way (Levitt's way Similarly, this process uses strict qualitative methods to integrate existing 
qualitative studies. It is to create more meaning through an interpretive process.

\section{FINDINGS AND RECOMMENDATIONS}

Urgent action is needed from all to prevent a learning crisis from turning into a generational disaster. Education is not only a fundamental human right. It is a right of action that has a direct bearing on the realization of all other human rights. It is the foundation of a global community of good and progress across the 17 Balanced Development Goals as the foundation for a just, equitable and integrated peaceful society. When education systems crumple, peaceful, fruitful and productive societies cannot be carried out. To mitigate the devastating effects of the COVID-19 Pandemic, government authorities and partners are motivated to track the following policy responses:

\section{Prevent the Transfer of Virus and Plan Support for School Resumption:}

The single most important step that countries can take to speed up the resumption of schools and educational institutions is to stop the spread of the virus to control national or local epidemics. Once they have done so, it is foremost to be guided by the following parameters to meet the complex challenge of reopening: ensure the safety of all; Comprehensive reopening plan; Listen to the voices of everyone involved; Coordinate with key actors, including the health community.

\section{Finance and Coordination for Education:}

The Pandemic World has been plunged into a deep global recession of life memory, which will permanently affect economies and public finances. The national authorities and the international community need to protect education funding in the following ways: strengthen domestic revenue collection, prioritize the allocation of expenditure on education, and address ineffectiveness in education spending; Strengthen international coordination to resolve debt crisis; Protect Developmental Personal Development Assistance (ODA)

\section{Build Resilient Education Systems for Qualified and Sustainable Development: \\ Strengthening the re-establishment of educational systems enables various countries to respond to the instant challenges of reopening schools safely and to better manage with future crises. In this regard, governments may consider: focusing on equity and inclusion; Strengthen the capacity for risk management at each and every levels of the system; Ensure strong leadership and coordination; And increase consultation and communication systems.}

\section{Change in education and learning:}

Reminds that change is feasible with the great attempts made in a short period of time to react to the impacts on education systems. We must seize the opportunity to find new ways to solve the learning crisis, and come up with a set of solutions that were previously thought to be difficult or impossible to implement. The following entry points may be at the frontline of our efforts: Focusing on learning loss and preventing drop outs, especially marginalized group.

According to the World Health Organization [WHO], $10,70,08,787$ cases were confirmed worldwide, 23,36,359 deaths were confirmed, and as of February 9, 2021, the virus had infected 213 countries.
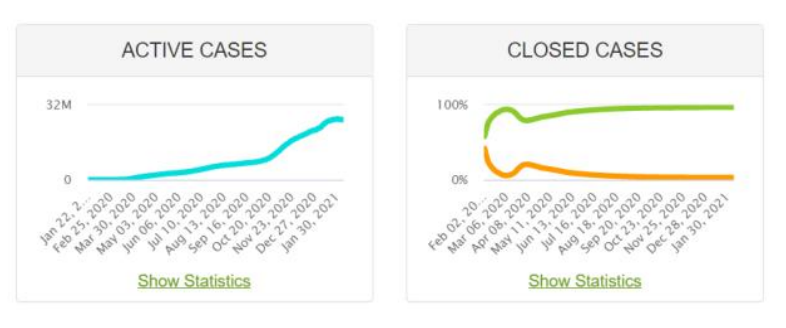

Fig-1 UNESCO report on active and closed Covid-19 Cases (January, 2021)

In the circumstances of emerging and changing COVID-19 (see Figure 1), many countries are affected by COVID-19. Similarly, many universities are closed or on the verge of being physically closed, and are moving to distance education online. For example, New York University in Shanghai and Duke Kunshan University provide examples of successful adaptation and rapid deployment of educational technology products such as the Zoom video conferencing platform and Moodle. It should be noted that they have previous experience to expand with these technologies. from scratch with new and unproven technological solutions (Czernowitz, 2020). Similarly, some schools in Australia are undergoing a rapid shift towards online learning. Similarly, institutions rapidly innovate and implement online learning because of their familiarity with the necessary tools, teaching approaches, and considerations related to online learning. This has hampered many students who cannot return to individual classes.

There isn't any doubt that establishments that don't have such preparations and designing steps got to be enforced currently to avoid the excessive demands and tensions caused by the fast adoption of things. there's a transparent would like for post-secondary on-line learning skills during this crisis, and it ought to function a reminder that institutions need to develop this ability. Universities within the world organization have closed to retardation the unfold of COVID-19, a respiratory organ infection that has killed quite 106,138 individuals worldwide. Governments round the world are searching for ways in which to stay students safe whereas finding ways to continue giving courses on-line. The literature shows that education directors request employees to collaborate and share data and digital infrastructure to show online in selected and latched areas (Czernowitz, 2020). Countries most tormented 


\section{International Journal of Engineering Applied Sciences and Technology, 2021 \\ Vol. 5, Issue 10, ISSN No. 2455-2143, Pages 11-19 \\ Published Online February 2021 in IJEAST (http://www.ijeast.com)}

by the virus do their best to continue teaching. For example, European country was the primary world organization member to shut down universities and move courses online before the whole country was subjected to a shipping ban.

Similarly, face-to-face teaching in any respect universities in Denmark, Greece, Ireland, Hungary Poland and alternative elements of the planet has been suspended. Similarly, in Italy, the University of Bologna extended the temporal order of tuition fees and issued generic SIM cards to students while not access to the Internet. In Romania, when the govt closed all schools, several universities affected their courses on-line as a precaution. Social distance is very important as universities across Europe are bolted bent on started the technology required to maneuver courses, exams, research, and other activities online. The University of capital of Poland has canceled all lectures and categories if not conducted on-line. victimization constant token, European nation determined to maneuver lectures online "as way as possible" and cancel large-scale events. employees' members were asked to figure from home the maximum amount as possible. The literature reveals that universities round the world are taking responsibility and doing their best to slow the unfold of the corona virus. in keeping with Czernowitz (2020), this transformation is critical as a result of the present COVID-19 scenario demands the security of scholars and teaching staff.

\section{The Politics of Defense}

Education directors know that technology is never neutral and that any change has a certain degree of resistance and controversy. Unnecessary protests and dissent in COVID-19 regarding the choice to use "online" and "blended learning" have become political and politicized. Mixed study has been attracted to current political agendas and has made serious claims that one mode is better than the other (Czernowitz, 2020). Gucci ideas thrive and people with finite ICT knowledge spread baseless lies about online, mixed learning (Huang et al., 2020). Some believe that face-to-face is better than online and mixed mode. This period will lead to unexpected political reactions. Compared to face-to-face mode, fake news like online degradation and mixed mode can certainly infiltrate the system and cause problems and uncertainty.

The World Bank assumes that very little awareness has been rewarded to documenting and analyzing efforts to move education systems fast and on scale to furnish online or distance learning when all educational institutions are closed (World Bank, 2020b). Even UNESCO knows that the transition to online learning on a scale is too difficult and complex endeavor to educational systems, even in the best of situations, but states that it has become a demand (UNESCO, 2020). During the period of challenges and dissent, universities began to go online differently depending on their specific institutional context. Be conscious that now no longer best do you need to layout techniques which might be suitable for unique contexts, however additionally make technical choices that mirror the present differences, alliances, discourses, and views of unique organizations (Murgatroyd, 2020). This can also additionally appear like the remaining issue on one's mind, however it's miles essential to understand what message is being dispatched while explaining the want to update face-to-face coaching with digital alternatives. At the time of the protest, the overall time period turned into combined study. All college establishments want to paintings collectively to efficiently release on-line and distance learning. Curriculum and different logistics want to be considered, and assessment responsibilities want to be re-tested and changed with assignments to keep away from face-to-face very last exams. Acceptance and compliance through all individuals will now no longer simply lessen immunity, however may also allow the implementation of on-line and distance learning, mainly in instances of catastrophe inclusive of the COVID-19 pandemic.

\section{Infrastructure Support}

The World Bank is concerned about the fact that even some education systems that are well resourced to offer such a large amount of online learning to all students may not be well equipped. Technological advances often outweigh the ability of solution makers in terms of cost and basic assistance (World Bank, 2020b). Appropriate ICT support is required on infrastructure, tools, systems that supports software and hardware; to provide effective online and mixed learning. There isn't any doubt that the integration of ICT as a teaching tool in academia has grown rapidly. Universities and colleges then began to implement applications such as Moodle and Educational Blogs in addition to existing teaching and training (Becker, 2000). Similarly, Rousseau (2005) (Becker, 2000) acknowledges that the provision of online resources in addition to traditional teaching methods is common in higher educational institutions. A study by Lee and Hsiao (2014) confirms that students' responses to items related to technology indicate that most of the students use information technology and related technologies. Similarly, going online does not seem to be a drastic change for many universities in the world. However, students should consider readiness and access to techno technology gadgets during most of the times. The meta-synthesis of relevant literature mentions that in recent years, there have been a growing interest in the development and use of multimedia-enriched content through the use of ICT to elaborate the quality of teaching and learning (CoSN, 2020; Smith \& JD, 2020; UNESCO, 2020; World Bank, 2020b). Multimedia content is a digital instructional material that combines text, graphics, audio, and animation. Teachers use this content to make better use of classroom lessons in expressing and explaining difficult ideas that can't be simply explained with lessons (Lanzilotti, Ardito, Costabile, de Angeli, 2006; Thomas \& Israel, 2013). Studies show that the proper use of multimedia enriched content in the educational situation offers a number of benefits. According to Lee, Hsiao and Ho (2014) of ICT tools help students improve 


\section{International Journal of Engineering Applied Sciences and Technology, 2021 \\ Vol. 5, Issue 10, ISSN No. 2455-2143, Pages 11-19 \\ Published Online February 2021 in IJEAST (http://www.ijeast.com)}

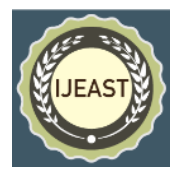

their understanding of instant teaching materials. They can simulate real processes and allow learners to perform virtual experiments, otherwise it can be done in a dangerous and expensive school laboratory (Hennessy, Deaney, \& Ruthven, 2006). In particular, the speed of technological repetition needs to be accelerated, and the technical application of online education programs needs to be optimized in light of the devastating impact of the COVID-19 pandemic.

\section{Staff Readiness}

Meta-Synthesis exhibits that readiness to adapt to extrade is an essential requirement for the a hit integration of era, because it presents college students with possibilities to examine and follow the essential abilities of the twenty first century (Sadegül Akbaba, Kalayci, \& Avci, 2011). The American Psychological Association, one of its recommendations, has recommended academics to recall enforcing an ICT included gaining knowledge of surroundings for college students ( $\mathrm{Li}$, Yamaguchi, \& Takada, 2018). In this regard, Vrasidas (2015) is pretty skeptical due to the fact institutions may also have the essential ICT facilities, however there can be different shortcomings such as loss of time for lesson education and unsupported curriculum design. He reiterates that ICT does now no longer suggest that there aren't anyt any sources that may be easily applied however that the presence of different aid additives is essential and that one such aspect is workforce readiness (Vrasidas, 2015). That is why Tapscott (1998) emphasizes the want for ok schooling and aid in ICT and pedagogy earlier than efficaciously integrating ICT. There isn't anyt any doubt as to why workforce willingness and motivation have to be taken into consideration as the important thing elements for a hit adoption of era in $\mathrm{HE}$ organizations. An in advance take a look at via way of means of the writer found out that a few workforce contributors at a higher-stage organization appear to combine ICT into their lessons, especially in lectures and tutorials, despite the fact that the majority (92\%) nonetheless agree with that self-belief is a component that can be in addition improved (Ali, 2019). This loss of self-assurance may be due to the management of various equipment and gaining knowledge of platforms. In a comparable note, Huang \& Liao (2005) asserts that the mindset of group of workers individuals and their willingness to enforce ICT could make a massive distinction withinside the lives in their college students. This is because, if the officials aren't equipped and the ICT isn't always enforcing the embedded study, their college students may be given verbal gaining knowledge of and chalk and board explanations. Yuvan and Mai (2002) percentage comparable sentiments, strongly recommending the want to empower coaching group of workers and construct their self-assurance if you want to enforce ICT incorporated coaching. In view of the COVID-19 pandemic, the World Bank says that officers running on-line want to study and supported. They warn that group of workers who do now no longer have ok broadband and home-related gadget will now no longer be capable of guide college students' gaining knowledge of on-line (World Bank, 2020b). They then request that the group of workers be technically, socially and ethically supported to correctly supply on-line classes.

\section{Student Accessibility}

Today's college students are recognized through many names, which includes Digital Indigenous (Prensky, 2001), Millennial (He \& Stross, 2000), Net Generation (Tapscott, 1998), and Digital Generation (Sommer,2014). Their access into the sector got here at a time while the unfold of generation become universally popular all around the world. An in advance observe through the writer discovered that scholars have a sturdy reference to ICT (Sommer,2014). Today's kids are uncovered to technological devices which includes cellular telephones and pills round the sector (Shava, Chinyamurindi, Somadyala, 2016). An empirical observe through Jesse (2015) confirms the above opinion, due to the fact his findings screen that the huge majority $(99.8 \%)$ of college students have cellular telephones that they use for texting, touring social media, speaking and applications. Looking on the fee at which generation has been integrated into the training system, college students can anticipate that it's miles surprisingly perfect and perfect. Similarly, a few paradoxes and illusions associated with internet era need to be taken into consideration as a lethal false impression that the ICT is aware of everything. The World Bank (2020A) stocks comparable sentiments, pointing college students and instructors to big online repositories, pronouncing that without right guidance, COVID-19 could now no longer be the exceptional in the course of a deadly disease lockdown. Although they may be technicians, they will now no longer have the theoretical know-how base required for a selected job. Evidence of help may be determined withinside the observe of O'Sullivan (2018), who strongly argues that many younger folks who are known as virtual natives have proven barriers of their use of generation. Numerous researches were performed round the sector, and this sort of observe in 2014 shows a big hole among the misconceptions of younger humans and their real know-how of pc skills (Somer, 2014). COVID-19 The Pandemic World Bank reiterates that maximum college students could have superb issue getting access to on-line learning, specially people with restrained get admission to the Internet and lots of different disadvantages (World Bank,2020b).

\section{Making it Happen}

There isn't any doubt that ICT has turn out to be a critical a part of regular existence and the gaining knowledge of surroundings has turn out to be a demand for ICT literacy for nearly all qualifications. The integration of generation in training has modified now no longer most effective the manner college students examine, however additionally the coaching of coaching with the aid of using selling collaborative activities (Haddad, 2003). Online gaining 


\section{International Journal of Engineering Applied Sciences and Technology, 2021 \\ Vol. 5, Issue 10, ISSN No. 2455-2143, Pages 11-19 \\ Published Online February 2021 in IJEAST (http://www.ijeast.com)}

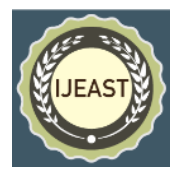

knowledge of environments nurture extra gaining knowledge of reports that permit beginners to communicate, collaborate, and benefit possession in their very own gaining knowledge of at their very own tempo and time. Therefore, ICT immersed classes now no longer most effective offer an inspiring and motivating gaining knowledge of surroundings for our college students, however additionally cause self-directed gaining knowledge of. As extra beginners pass from instructormanaged surroundings to instructor-managed surroundings, the function of the instructor will become extra facilitator and calls for much less scaffolding (Geng, Law, Niu, 2019). Clearly, contributors of the coaching team of workers withinside the shape of professors, academics, and coaching assistants play a key function withinside the powerful implementation of ICT incorporated gaining knowledge of (Aidin, 2012; Bubeng-Ando, 2015; Cipila, 2011). Therefore, it's far critical for them to have the proper mindset and knowhow approximately ICT if you want to combine generation in coaching. Similarly, college students' perceptions and aspirations want to be taken into consideration because it at once impacts their vicinity of examine and style (BubengAndo \& Totime, 2012; Fu, 2013; Jung, 2005; Mirzajani, Mahmoud, Fouci Mohammed Ayub, \& Wong, 2016). The remarkable state of affairs of COVID-19 has created demanding situations for team of workers, college students, and directors to embody on-line gaining knowledge of. There isn't anyt any doubt that the tremendous technological advances withinside the global call for a paradigm shift withinside the manner we method our tutorial desires and aspirations. Many universities and academic establishments have followed ICT gadgets consisting of laptops, projectors, tablets, smartphones, iPods, and interactive whiteboards. This is further to many academic software programs and gaining knowledge of packages which might be quite simply to be had at the Internet. Similarly, the findings monitor that team of workers contributors have observed that scholars have a unique dating with ICT. They consider that today's college students are completely linked to cell generation and are awaiting generation incorporated gaining knowledge of. Not least, the IC ICT reputation of college students is nicely acquired with the aid of using all. In a comparable note, Buabeng-Ando and Yidana (2014) trust Erle (2002)'s imaginative and prescient of college students searching out ICT incorporated gaining knowledge of, in addition to assisting them examine the Internet and examine classes from the consolation in their very own homes. This motivation in college students calls for academics and directors to offer ok ICT infrastructure and scholar assist offerings to make gaining knowledge of significant and exciting for all. In summary, it may be concluded that academics and coaching team of workers are key gamers withinside a success implementation of ICT incorporated gaining knowledge of, and that they want to price every different and assist accordingly.

However, the World Bank has raised some of demanding situations due to the fact training companies are speeding to move on line, in order that COVID-19 does now no longer have an effect on college students' training for the duration of instances of retaining social distance among epidemics.

Some of the troubles raised via way of means of this are:

- Switching from on line to on line studying scale is a completely hard and really complicated enterprise for training structures, even withinside the first-rate of circumstances;

- Moving to on line studying on a scale increases profound fairness concerns;

- Highly influenced learners, mainly people with preceding revel in in on line studying, are possibly to make the maximum of on-line studying opportunities;

- When going on line for the primary time, training structures and mother and father must limit the advantages to short-time period college students;

- Organizing virtual training content material in step with Cribe's current curriculum is essential in imparting a manner for customers and instructors to make certain that they healthy into the wider instructional dreams of a training system;

- Devices Content availability throughout quite a few gadgets and cellular buddies is crucial;

- Support for low bandwidth use, which includes offline solutions, is essential for powerful studying;

- Online coaching group of workers want help;

- Universities want to barter with Internet providers to assist college students advantage get right of entry to homes. on line studying on line or at low cost

- Providing applicable steering and help on a way to use and get right of entry to remote, on line studying content material;

- In addition, academy states that a few instructional topics are simpler to transport on line than others (World Bank, 2020b)

The World Bank states that it is easier to move academically online academic subjects, which are mainly lectures based and lend to self - study. Learning content already offers digitized topics, especially when it is clearly aligned with the official formal school curriculum, offering better applicants for online study than those who do not. The World Bank warns absolutely each person to take care that maximum of what occurs in instructions can't be effortlessly transmitted on-line. Instructional approaches, content, pacing, interplay models, and assessment all want to be matched whilst switching to online learning (World Bank, 2020b). All of those techniques may be time consuming, however a start-up wishes to be commenced as it isn't a count number of choices, however a reaction to the COVID-19 Pandemic.

Limitations 


\section{International Journal of Engineering Applied Sciences and Technology, 2021 \\ Vol. 5, Issue 10, ISSN No. 2455-2143, Pages 11-19 \\ Published Online February 2021 in IJEAST (http://www.ijeast.com)}

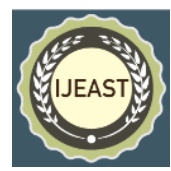

Naturally, the study has a look at has a few limitations, wherein case it's miles the most effective technique used to acquire data. The outcomes of this have a look at couldn't be proven with the aid of using survey and different unbiased measures due to the fact most effective meta-evaluation turned into used withinside the have a look at. Consequently, those outcomes need to be visible as a photo of on line studying as a choice for better training in mild of the excessive effect of the COVID-19 pandemic. Therefore, exploratory findings gift an effective platform for dialogue and dialogue and an effective release pad for extra in-intensity studies at the topic.

\section{CONCLUSION}

Internationally, Governments have taken drastic measures such as maintaining national lockdowns and maintaining social distance in an effort to prevent the spread of the deadly COVID-19 and its spread. These regulations have induced many universities and Higher Educational institute to choose online have a look at to save you the unfold of the corona virus. It is consequently recommended:

- The issues raised with the aid of using the World Bank recognized in this text on line ought to be taken into consideration while adopting on line and distance studying;

- Learning HE establishments want primary ICT infrastructure to correctly expand on line studying;

- $\quad$ Staff want ICT system and feature get admission to programs and studying platforms;

- Staff participants want the capacity to apply ICT equipment correctly to offer training in one of these modes;

- Understand body of workers and pupil willingness and help accordingly.

Moreover, the pandemic and social distancing requirement of COVID-19 has posed useless demanding situations for all contributors to go surfing due to the fact they want to paintings inside time constraints and useful resource constraints. It needs to be mounted that adopting a web gaining knowledge of surroundings isn't always a technical issue. This is a pedagogical, coaching challenge. Similarly, ok instruction for coaching materials, curriculum, and evaluation expertise is crucial in on-line schooling. Technology is a device for delivery, and calls for near collaboration with instruction, content, and technical teams. Closing universities and putting off college students and teachers from the study room is a pedagogical transformation that desires to be swiftly mobilized throughout all college group of workers and resources (CoSN, 2020). In short, ICT has turn out to be an effective pressure for converting the instructional panorama across the world. However, getting ready to transport schooling outdoor of conventional bodily school rooms in reaction to COVID-19 calls for thought, coordination, and cautious decision-making. This record is a start line for making plans and helping a crucial gaining knowledge of transition. We need to be constructive as literature has an excessive degree of scholar delight and hobby in an immersive gaining knowledge of surroundings in ICT. Technology has had a large effect on the web lives of younger people. This digitalized revolution can combine the instructional aspirations and hobbies of college students who've turn out to be digitally addicted. In short, the fast emergence of Covid-19 new technology has given us the possibility to embody on-line gaining knowledge of as instructional structures combine, consequently making on-line, mixed, and distance gaining knowledge of obligatory now no longer simplest in Sudan, however additionally on the higher-degree degree across the world.

\section{REFERENCE}

[1] Ali, W. (2019). The Efficacy of Evolving Technology in Conceptualizing Pedagogy and Practice in Higher Education. Journal of Higher Education $\quad$ Studies, 9(2), 81-95. https://doi.org/10.5539/hes.v9n2p81

[2] Aydin, S. (2012). A review of research on Facebook as an educational environment. Educational Technology, Research and Development, 60(6), 1093-1106. http://dx.doi.org/10.1007/s11423-0129260-7

[3] Becker, H. J. (2000). Who's wired and who's not: Children's access to and use of computer technology. The Future of Children, 10(2), 44-75. https://doi.org/10.2307/1602689

[4] Buabeng-Andoh, C., \& Totimeh, F. (2012). Teachers' innovative use of computer technologies in classroom: A case of selected Ghanaian schools. International Journal of Education and Development using Information and Communication Technology, 8(3), 22-34.

[5] Buabeng-Andoh, C., \& Yidana, I. (2014). An investigation of secondary school students' attitudes toward pedagogical use of ICT in learning in Ghana. Interactive Technology and Smart Education, 11(4), 302-314. https://doi.org/10.1108/ITSE-10-2013-0024

[6] CoSN. (2020). COVID-19 Response: Preparing to Take School Online. Retrieved from https://www.cosn.org/sites/default/files/COVID19\%20Member\%20Exclusive_0.pdf

[7] Czerniewicz, L. (2020). What we learnt from "going online" during university shutdowns in South Africa. Retrieved from https://philonedtech.com/what-we-learnt-fromgoing-online-during-university-shutdowns-insouth-africa/ 
[8] Earle, R. S. (2002). The Integration of Instructional Technology into Public Education: Promises and Challenges. Educational Technology \& Society, 42(1), 5-13.

[9] Fu, J. S. (2013). ICT in Education: A Critical Literature Review and Its Implications. International Journal of Education and Development using Information and Communication Technology, 9(1), 112-125.

[10] Geng, S., Law, K., \& Niu, B. (2019). Investigating self-directed learning and technology readiness in blending learning environment. International Journal of Educational Technology in Higher Education, 16. https://doi.org/10.1186/s41239-019$\underline{0147-0}$

[11]Hennessy, S., Deaney, R., \& Ruthven, K. (2006). Situated expertise in integrating use of multimedia simulation into secondary science teaching. International Journal of Science Education, 28(7), 701-732. https://doi.org/10.1080/09500690500404656

[12]Huang, H. M., \& Liaw, S. S. (2005). Exploring user ${ }^{\text {ee }} \mathrm{s}$ attitudes and intentions toward the web as a survey tool. Computers in Human Behavior, 21(5), 729-743. https://doi.org/10.1016/j.chb.2004.02.020

[13]Huang, R. H., Liu, D. J., Tlili, A., Yang, J. F., \& Wang, H. (2020). Handbook on Facilitating Flexible Learning During Educational Disruption: The Chinese Experience in Maintaining Undisrupted Learning in COVID-19 Outbreak. Retrieved from https://iite.unesco.org/wpcontent/uploads/2020/03/Handbook-on-

Facilitating-Flexible-Learning-in-COVID http://hes.ccsenet.org Higher Education Studies Vol. 10, No. 3; 202024 -19-Outbreak-SLIBNUV1.2-20200315.pdf

[14] Jesse, G. R. (2015). Smartphone and App Usage Among College Students: Using Smartphones Effectively for Social and Educational Needs. Retrieved from http://proc.iscap.info/2015/pdf/3424.pdf

[15] Jung, I. (2005). ICT-Pedagogy Integration in Teacher Training: Application Cases Worldwide. Journal of Educational Technology \& Society, 8(2).

[16] Lanzilotti, R., Ardito, C., Costabile, M. F., \& DeAngeli, A. (2006). ELSE methodology : a systematic approach to the e-learning systems evaluation. Educational Technology \& Society, 9(4), 42-53.

[17]Lee, Y., Hsiao, C., \& Ho, C. H. (2014). The effects of various multimedia instructional materials on students $^{\text {ee }}$ learning responses and outcomes: A comparative experimental study. Computers in Human Behavior, 40, 119-132. https://doi.org/10.1016/j.chb.2014.07.041
[18] Levitt, H. M. (2018). How to conduct a qualitative meta-analysis: Tailoring methods to enhance methodological integrity. Review PMID, 28(3), 367-378. https://doi.org/10.1080/10503307.2018.1447708

[19]Li, S., Yamaguchi, S., \& Takada, J.-i. (2018). Understanding factors affecting primary school teachers' use of ICT for student-centered education in Mongolia. International Journal of Education and Development using Information and Communication Technology, 14(1), 103-117.

[20] Mirzajani, H., Mahmud, R., Fauzi Mohd Ayub, A., \& Wong, S. L. (2016). Teachers' acceptance of ICT and its integration in the classroom. Quality Assurance in Education, 24(1), 26-40. https://doi.org/10.1108/QAE-06-2014-0025

[21] Murgatrotd, S. (2020). COVID-19 and Online Learning.

[22] O'Sullivan, D. (2018). Schools' role in addressing the Digital Native Fallacy. Retrieved from http://www.bcs.org/content/ConWebDoc/55719 Prensky, M. (2001). Digital Natives, Digital Immigrants. On the Horizon, 9(5), 1-6. https://doi.org/10.1108/10748120110424816

[23] Sadegül Akbaba, A., Kalayci, E., \& Avci, Ü. (2011). Integrating ICT at the Faculty Level: A Case Study. TOJET : The Turkish Online Journal of Educational Technology, 10(4).

[24] Shava, H., Chinyamurindi, W., \& Somdyala, A. (2016). An investigation into the usage of mobile phones among technical and vocational educational and training students in South Africa. South African Journal of Information Management, $18(1)$, $1-8$. http://dx.doi.org/10.4102/sajim.v18i1.716

[25] Sommer, H. (2014). Digital competence study. Intermediate results. Retrieved from https://www.youtube.com/watch?v=BtAFgBiTb5g

[26] Stadler-Altmann, U. (2015). Learning Environment: The Influence of School and Classroom Space on Education. p. 252-262.

[27] Tapscott, D. (1998). Growing Up Digital: The Rise of the Net Generation. New York: McGraw-Hill.

[28] Thomas, O. O., \& Israel, O. O. (2013). Effectiveness of animation and multimedia teaching on students ${ }^{\text {ee }}$ performance in science subjects. British Journal of Education, Society \& Behavioural Science, 4(2), 201-210. https://doi.org/10.9734/BJESBS/2014/3340

[29] UNESCO. (2020). COVID-19 Educational Disruption and Response. Retrieved from https://en.unesco.org/covid19/educationresponse/

[30] Vrasidas, C. (2015). The rhetoric of reform and teachers $^{\text {ee }}$ use of ICT. British Journal of 
International Journal of Engineering Applied Sciences and Technology, 2021

Vol. 5, Issue 10, ISSN No. 2455-2143, Pages 11-19

Published Online February 2021 in IJEAST (http://www.ijeast.com)

Educational Technology, 46(2), 370-380. https://doi.org/10.1111/bjet.12149

[31] World Bank. (2020b). Remote Learning and COVID19 The use of educational technologies at scale across an education system as a result of massive school closings in response to the COVID-19 pandemic to enable distance education and online learning. Retrieved from file:///E:/PC/RapidResponse-Briefing-Note-Remote-Learning-andCOVID-19-Outbreak.pdf

[32] Yuen, A., \& Ma, W. (2002). Gender differences in teacher computer acceptance. Journal of Technology and Teacher Education, 10(3), 365382. 